\title{
The role of Nogo-A in axonal plasticity, regrowth and repair
}

\section{Journal Article}

\section{Author(s):}

Pernet, Vincent; Schwab, Martin E.

Publication date:

2012-07

Permanent link:

https://doi.org/10.3929/ethz-b-000050970

Rights / license:

In Copyright - Non-Commercial Use Permitted

Originally published in:

Cell \& Tissue Research 349(1), https://doi.org/10.1007/s00441-012-1432-6 


\title{
The role of Nogo-A in axonal plasticity, regrowth and repair
}

\author{
Vincent Pernet • Martin E. Schwab
}

Received: 2 March 2012 / Accepted: 5 April 2012 /Published online: 17 May 2012

(C) Springer-Verlag 2012

\begin{abstract}
Axonal damage leads to permanent deficits in the adult central nervous system (CNS) not only because of the weak intrinsic ability of adult neurons to activate their growth program but importantly also because of the presence of specific growth inhibitors in the CNS tissue and the environment of the damaged axons. The well-studied myelin-derived protein Nogo-A is involved in various cellular and molecular events contributing to the failure of CNS axons to regrow and reconnect after transection. Recent studies have shown that, by acting in a negative way on the cytoskeleton and on the growth program of axotomized neurons, Nogo-A exerts fast and chronic inhibitory effects on neurite outgrowth. On the other hand, the blockade of Nogo-A results in a marked enhancement of compensatory and regenerative axonal extension in vivo; this enhancement is often paralleled by significant functional recovery, for example, of locomotion or skilled forelimb reaching after spinal cord or stroke lesions in rats and monkeys. Surprisingly, the blockade of Nogo-A or its receptor $\mathrm{NgR}$ in the hippocampus has recently been demonstrated to enhance longterm potentiation. A role of Nogo-A in synaptic plasticity/ stability might therefore represent an additional, new and
\end{abstract}

\section{Pernet $(\triangle)$}

Brain Research Institute, University of Zürich/ETH,

Department of Health Sciences and Technology ETH Zürich,

Winterthurerstrasse 190, Room 55J34a,

8057, Zürich, Switzerland

e-mail: pernet@hifo.uzh.ch

\section{E. Schwab ( $\square)$}

Brain Research Institute, University of Zürich/ETH,

Department of Health Sciences and Technology ETH Zürich,

Winterthurerstrasse 190, Room 55H52,

8057, Zürich, Switzerland

e-mail: schwab@hifo.uzh.ch important aspect of CNS circuit remodeling. Functionblocking anti-Nogo-A antibodies are currently being tested in a clinical trial for improved outcome after spinal cord injury.

Keywords Axonal damage $\cdot$ Nogo-A $\cdot$ Nogo-A receptor . Inhibition $\cdot$ Function-blocking antibodies $\cdot$ Long-term potentiation $\cdot$ Remodeling

\section{Nogo-A protein expression in the intact and injured central nervous system}

Nogo-A is a transmembrane protein of about 1200 amino acids (aa) including a C-terminal 200-aa reticulon (RTN) domain (Chen et al. 2000; GrandPre et al. 2000). It has been purified from mammalian central nervous system (CNS) myelin and is one of the most potent neurite growth inhibitors in CNS myelin and tissue (Spillmann et al. 1998). Nogo-A is mainly expressed by oligodendrocytes in the adult CNS (Huber et al. 2002; Wang et al. 2002b). The high endogenous expression of Nogo-A by oligodendrocytes shows little increase around a spinal cord injury site (Huber et al. 2002). Before myelin formation, Nogo-A is strongly expressed by developing and immature neurons and neuronal Nogo-A persists at a high level in plastic CNS regions such as the cortex, the hippocampus and dorsal root ganglia (Huber et al. 2002; Peng et al. 2011). The presence of Nogo-A in plastic areas of the adult CNS appears paradoxical and suggests additional functions unrelated to axonal plasticity. Nevertheless, after axonal severing in the optic nerve, we have observed an up-regulation of Nogo-A that is most striking in a subpopulation of retinal ganglion cells with larger soma sizes (Pernet et al. 2011). In the pyramidal neurons and interneurons of the cortex, increased Nogo-A levels have been seen in stroke perilesional areas (Cheatwood 
et al. 2008). The functions of Nogo-A under these conditions of neuronal damage are not known.

\section{Nogo-A neutralization or knock-out or Nogo receptor suppression enhances axonal growth after injury}

The functional deficits after spinal cord injury depend on the location and severity of the damage. In the case of an incomplete spinal cord lesion, a spontaneous remodeling of intraspinal circuits, e.g., by the formation of detour pathways, contributes to the recovery of hindlimb function (Bareyre et al. 2004). Under more severe lesion conditions in which recovery is not observed, the intrathecal infusion of function-blocking anti-Nogo-A antibodies significantly improves sensory-motor functions and stimulates axonal sprouting from damaged and intact fibers (Thallmair et al. 1998; Raineteau et al. 2001; Liebscher et al. 2005; Freund et al. 2006, 2009; Gonzenbach et al. 2012). Long-range axonal regeneration and increased compensatory growth of intact fibers have been observed after the application of various antiNogo-A antibodies. A delay in the delivery of these antibodies by 1 week but not 2 weeks, is efficient to increase corticospinal tract axon regeneration over several millimeters after dorsal thoracic spinal cord lesion (Gonzenbach and Schwab 2008). Consistent with this, hindlimb function is improved when antibody infusion begins no later than 1 week after injury. In contrast, in a rat stroke model, skilled forelimb movements recover, even when anti-Nogo-A treatment is started as late as 9 weeks after ischemic brain damage (Tsai et al. 2011). Importantly, similar anatomical and behavioral results have been obtained with reagents blocking the Nogo receptor NgR1 ( $\mathrm{Li}$ and Strittmatter 2003; Lee et al. 2004; Wang et al. 2006, 2011), the NgR-associated protein Lingo-1 (Ji et al. 2006), or the downstream signaling components RhoA (Dergham et al. 2002; Fournier et al. 2003; Lord-Fontaine et al. 2008) or ROCK (Fournier et al. 2003; Duffy et al. 2009). All these findings not only establish a strong proof-of-principle for the clinical use of Nogo-A immunotherapy in different CNS injury types but also raise interesting questions about the normal physiological role played by Nogo-A in the complex CNS of higher vertebrates.

Function-blocking antibodies directed against Nogo-A have been extensively used by our group and have allowed us to develop a potential therapy to treat human CNS injuries and diseases. In vivo experiments in rats and in monkeys represent essential preclinical tests to validate the efficiency and safety of Nogo-A antibody administration. In non-human primates, the dexterity of the paralyzed arm and hand after a cervical hemisection is almost completely restored by the intrathecal delivery of a Nogo-A-specific antibody (Freund et al. 2006, 2009). Fine motor movement recovery is associated with a large amount of corticospinal axon sprouting past the lesion site and innervation of the lower cervical cord segments. The concept of therapeutic antibody administration in the CNS was first tested in clinical trials targeting Nogo-A; the anti-human Nogo-A antibody ATI355 produced in collaboration with Novartis Pharma (Basel) has recently been established as being safe for patients with spinal cord injuries in a Phase I clinical trial (http://clinicaltrials.gov/ct2/show/ NCT00406016) with 52 acutely injured, severe para- and tetraplegic patients (Abel et al. 2011). A placebo-controlled Phase II clinical trial is currently in preparation. In another CNS disease, amyotrophic lateral sclerosis (ALS), the ectopic expression of Nogo-A at the neuromuscular junction is an early sign of the disease and is thought to cause synapse destabilization and thereby motor control loss (Dupuis et al. 2002; Jokic et al. 2005, 2006). As has been proposed for spinal cord injury, GlaxoSmithKline (GSK) has developed a humanized anti-Nogo-A antibody (GSK1223249) to prevent Nogo-A-induced synaptic destabilization and motoneuron degeneration in ALS (http://clinicaltrials.gov/ct2/show/ NCT00875446). Preliminary results of a Phase I clinical trial have recently been presented (Pradat et al. 2011). Intravenous injections of GSK1223249 appear to be well tolerated by the 76 patients enrolled in the trial. A larger Phase II international trial is scheduled for 2012 to assess the therapeutic benefits of GSK1223249 on ALS symptoms.

\section{Molecular mechanisms mediating Nogo-A-induced axonal growth inhibition}

\section{Cell surface Nogo-A}

\section{Cytoskeleton regulation}

Two principal domains of Nogo-A have been shown to exert inhibitory effects on neurite outgrowth: the Nogo-66 sequence in the C-terminal RTN region and a 160-aa fragment called Nogo-A delta20 in the Nogo-A-specific region (Oertle et al. 2003b). A clear mechanism has been elucidated for Nogo-66mediated growth inhibition; a receptor complex composed of the Nogo-66 receptor NgR1, a glycosyl-phosphatidylinositollinked leucine-rich repeat protein (Fournier et al. 2001) and the NgR1-associated proteins Lingo (Mi et al. 2004) and p75 (Wang et al. 2002a) or Troy (Shao et al. 2005) is stimulated by Nogo-66 leading to the intracellular activation of the RhoA/ ROCK/cofilin pathway that prevents actin cytoskeleton polymerization in the growth cone and thereby blocks neurite extension (Nash et al. 2009; Fig. 1). Consistent with this, in Nogo-A knock-out (KO) mice, growth cone motility is increased compared with wild-types (Montani et al. 2009). Surprisingly, the same receptor complex and downstream mechanisms seem also to be involved in the growth inhibitory effects of other myelin-associated proteins, such as 


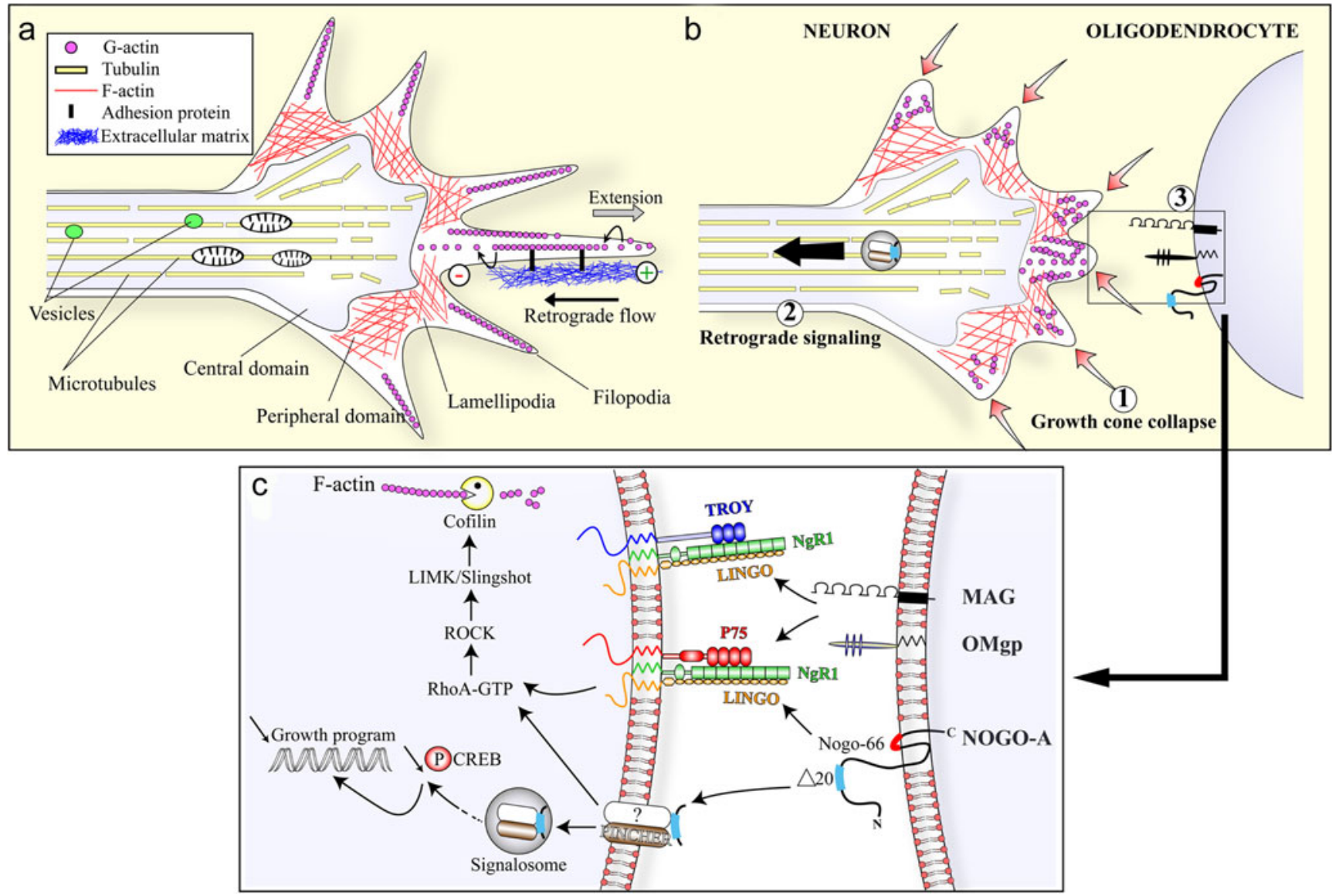

Fig. 1 Molecular mechanisms of Nogo-A-mediated axonal growth inhibition. a Organization of the growth cone. The growth cone is composed of a central domain containing the microtubules involved in the transport of organelles and of a peripheral domain in which actin filaments $(F$-actin) form a cytoskeleton meshwork in the lamellipodia and filopodia. The protrusion of the filopodia occurs at the plus end $(+)$ of the actin filament and is required to allow the traction of the growth cone on the extracellular matrix. b Growth cone inhibition. The contact of filopodial extensions with myelin-associated inhibitors such as Nogo-A (1) triggers the quick collapse of F-actin in the growth cone (2). The retrograde signaling is thought to mediate the long-term effects of Nogo-A on the repression of the neuronal growth program (3). c Nogo-66 and other myelin inhibitors exhibited at the cell surface

myelin-associated glycoprotein (MAG) and oligodendrocyte myelin glycoprotein (OMgp) (Wang et al. 2002a). One way in which myelin-associated inhibitors activate the small GTPase RhoA might be by the phosphorylation and inactivation of GSK3beta, thereby allowing CRMP4 and RhoA interaction (Alabed et al. 2010).

Another receptor has recently been identified for Nogo-66, MAG and OMgp, called paired immunoglobulin-like receptor-B (PirB; Atwal et al. 2008). In primary neuron cultures, the blocking of PirB partially relieves the myelinprotein-induced inhibition of axonal outgrowth (Atwal et al. 2008). However, the genetic deletion of PirB alone fails to increase axonal growth in vivo after corticospinal tract transection (Nakamura et al. 2011), traumatic brain lesion (Omoto of oligodendrocytes bind to and stimulate a common neuronal receptor complex. The transduction of the signal passes through the intracellular activation of the RhoA/ROCK pathway and involves the actin-severing enzyme cofilin, a main effector in the disassembly of the growth cone cytoskeleton. Alternatively, the Nogo-A delta20 region is internalized by an unknown receptor via a pincher-dependent mechanism. The uptake of Nogo-A delta20 leads to the activation of the RhoA/ ROCK/cofilin cascade. In addition, the resulting molecular complex can also be retrogradely transported in signalosomes to the neuronal cell body in which it activates RhoA, negatively regulates phospho-CREB and thereby attenuates the neuronal growth program (abbreviations are explained in the text)

et al. 2010), or optic nerve crush (Fujita et al. 2011). As for $\mathrm{NgR} 1$, the regenerative and behavioral outcomes observed after PirB ablation might depend on the lesioned tract (Cafferty and Strittmatter 2006) or on (yet unknown) coreceptors. More work will be necessary to specify the contribution of PirB to the molecular mechanisms underlying axonal regeneration failure in vivo.

The biochemical mechanisms triggered by the Nogo-A domain Nogo delta20 in neurons remain more elusive. The receptor(s) bound by Nogo delta20 has(have) not been identified as yet. However, purified Nogo delta2 0 has been shown to destabilize the cytoskeleton, as has been found for Nogo-66, in a RhoA-dependent manner (Niederost et al. 2002; Joset et al. 2010). 


\section{The neuronal growth program}

The long-term effects of growth-promoting and growthrepressing molecules are often regulated at the gene expression level. Our group has recently demonstrated that growth cone collapse and RhoA activation require the Pincherdependent internalization of Nogo-A delta20 in primary neurons. In addition to affecting the growth cone cytoskeleton assembly, Nogo-A-delta20-containing signalosomes are retrogradely transported to the cell body in which they activate RhoA, downregulate cAMP response elementbinding protein (CREB) phosphorylation and repress the cellular growth program (Joset et al. 2010) (Fig. 1). Interestingly, a similar mechanism of retrograde signaling has previously been described for neurotrophic factors that exert opposite growth-promoting effects on axons and that activate neuronal plasticity (Shao et al. 2002). Strikingly, the group of Filbin has reported that neurotrophic factors can overcome myelin-associated protein-mediated growth inhibition by up-regulating cAMP and P-CREB, leading to the activation of arginaseI expression, a rate-limiting enzyme for the synthesis of polyamines (Cai et al. 2002; Gao et al. 2004). The signaling of negative and positive regulators of axonal growth might therefore converge on the same intracellular transcription factors. However, additional molecules controlling the cellular growth program might be changed after Nogo-A action, such as the signal transducer and activator of transcription (Stat; Bareyre et al. 2002) or the Akt (protein kinase B)-mTOR (mammalian target of rapamycin) pathway. Recent observations suggest that Nogo-A decreases synaptic protein translation by antagonizing the mTOR activation required in long-term potentiation (LTP; Baldwin et al. 2011). The role of those molecules and pathways remains to be clarified in the CNS (Bareyre et al. 2011).

At first glance, the presence of two inhibitory active sites within the Nogo-A sequence seems intriguing. However, interaction of more than one active site of a signaling molecule with more than one subunit of a multi-subunit receptor complex is well known, e.g., for neurotrophic factors, Wnt, semaphorins, or netrin (Schwab 2010). The two domains of Nogo-A might differ such that they mediate plasticity and growth repression. For Nogo-A delta20, shortand long-term inhibitory mechanisms might operate at the cytoskeleton and gene expression level, whereas Nogo-66/ $\mathrm{NgR} 1$ has been proposed to induce acute growth cone collapse and neurite growth inhibition but not chronic outgrowth blockade (Chivatakarn et al. 2007). A bimodal functioning of Nogo-A via its two domains activating distinct receptors or subunits might therefore contribute to the acute and chronic impairment of axonal plasticity. This could have relevance for the design of repair strategies for the lesioned CNS.
Intracellular and endoplasmic-reticulum-associated Nogo-A

\section{Role in survival and axonal regeneration}

On the basis of its 200-aa C-terminus, Nogo-A belongs to the RTN protein family, which is composed of four members (RTN1, RTN2, RTN3, RTN4) present in eukaryotes (Oertle et al. 2003a). Some structural and enzyme regulatory functions have been described for RTNs; they can influence the curvature of the endoplasmic reticulum (ER) and appear as structural regulators for the subcompartment "tubular ER" (Voeltz et al. 2006). RTNs can also interact with the anti-apoptotic intracellular proteins $\mathrm{Bcl}-2$ or $\mathrm{Bcl}-\mathrm{XL}$ and have therefore been claimed to play a role in cell death regulation (Tagami et al. 2000; Wan et al. 2007).

In ischemia and after oxidative stress, Nogo-A might act as a neuroprotective molecule. After middle cerebral artery occlusion, Nogo-A KO or the acute but not the delayed blockade of Nogo-A with antibodies decreases neuronal survival (Kilic et al. 2010). More recently, Nogo-A delta20 transfection in cortical neurons has been shown to protect against hydrogenperoxide-induced cell death in vitro, supposedly by interacting with the enzyme peroxiredoxin 2, which scavenges reactive oxygen species (Mi et al. 2012).

Nogo-A has been observed to increase in the cell body of injured neurons suggesting that it exerts cell-autonomous effects on cell death and/or growth mechanisms (Cheatwood et al. 2008; Pernet et al. 2011). ER stress is thought to play a role in many degenerative diseases such as ALS (Atkin et al. 2006; Saxena et al. 2009), Alzheimer's disease, or Parkinson's disease (Doyle et al. 2011). As an RTN protein, the expression of which can change in compromised neurons, Nogo-A is suspected of influencing ER stress activation. After optic nerve injury, we have observed that Nogo-A is up-regulated in neurons together with other ER-stress-associated markers such as the pro-apoptotic transcription factor CHOP (Pernet et al. 2011). However, we have been unable to detect a change in CHOP expression or in the frequency of apoptosis when injury-induced Nogo-A is silenced selectively in neurons or fully deleted genetically. Our results are consistent with previous in vitro data showing that Nogo-A over-expression does not enhance the level of CHOP or that of the chaperon protein Bip (Yang et al. 2009). Therefore, the axon lesion-induced upregulation of Nogo-A in neurons does not seem to be an important regulator of apoptosis in vivo.

Interaction of neuronal Nogo- $A$ with $\beta$-secretase (BACE1)

The production of $\beta$-amyloid deposits is a hallmark of Alzheimer's disease. Interestingly, the group of Yan has found in vitro that all RTN members including Nogo are able to bind and to inhibit the $\beta$-amyloid-converting enzyme 1 (BACE1), which transforms the amyloid precursor protein 
(APP) into aggregating $\beta$-amyloid (He et al. 2004). In vivo, however, the physiological role of RTNs in this context is less clear. The over-expression of RTN3 in transgenic mice reduces the production of $\beta$-amyloid in the hippocampus but concomitantly causes the formation of RTN3 aggregates in dystrophic neurites (Shi et al. 2009b). The excess of RTN might compete with APP to bind BACE1, thereby sequestering BACE1 in the ER and prevent its enzymatic activity on APP (Shi et al. 2009b). However, we do not know whether RTNs and in particular Nogo-A, serve as substrates for BACE1 and can be secreted, for example, as bioactive fragments into the extracellular space. In addition, the experimental over-expression of RTN3 might not faithfully reproduce pathophysiological conditions such as those encountered in aging brains (Shi et al. 2009a). Much remains to be learnt at present on the possible roles of Nogo and RTN proteins in the regulation of intracellular enzymes such as BACE1 or of processes such as ER function or cell survival.

\section{The re-formation of functional circuits after traumatic CNS lesions}

Function-blocking antibodies against Nogo-A, NgR1-blocking peptides, antibodies against Lingo-1, or pharmacological blockers of the signal transducers RhoA and ROCK have been applied in various laboratories in spinal cord injury and stroke models in rats, in mice and, in some instances, also in monkeys. Enhancement of behavioral recovery in a variety of sensory-motor tests and enhanced sprouting and longdistance regeneration of lesioned and spared axons have been found (Zorner and Schwab 2010). Importantly, a high degree of similarity is present despite using different ways to interrupt Nogo-A signaling. Similar but overall weaker and variable results have been obtained in Nogo KO mice in spinal cord injury studies (Kim et al. 2003; Simonen et al. 2003; Zheng et al. 2003; Dimou et al. 2006; Cafferty et al. 2010; Lee et al. 2010).

A defined succession of events probably controls the formation of functional reconnections in the damaged brain and spinal cord. A time window (1 week in the rat) seems to exist during which Nogo-A immunotherapy is efficient at activating spinal cord axon regeneration (Gonzenbach et al. 2012); the treatment with Nogo-A antibody has only weak behavioral and anatomical effects when delayed by 2 weeks after the injury compared with the acute or 1-week-delayed administration. The neuronal growth response occurring spontaneously after an axonal injury might condition the effects of Nogo-A neutralization on axonal regrowth. In the visual system, an intervention window has been defined in the growth-promoting inflammation paradigm; intraocular inflammation can only elicit axonal regeneration when the treatment is delivered 3 days before or after optic nerve crush injury but not after 7 days (Yin et al. 2003). The time-course of growth-associated-molecule expression has revealed that, soon after axon transection, neurons attempt but fail to regenerate. Thus, the neutralization of Nogo-A might also facilitate the growth of neurons early after injury. The mechanisms of guidance of regenerating axons in the adult CNS and the molecular determinants of target recognition have not been studied so far. We do not know whether sprouts and regenerating axons reconnect to their original targets in the spinal cord or brain, or whether synapse formation occurs randomly. Finally, mechanisms of stabilization and pruning of connections and synapses, probably driven by activity and use, might lead to the formation of new functional circuits.

\section{Nogo-A is a negative regulator of synaptic plasticity}

The expression of Nogo-A in neurons or in glial cells might also control the formation and stability of synaptic contacts after a lesion. Most of our knowledge on the effects of Nogo-A on synaptogenesis and synaptic transmission is derived from a few developmental studies and from electrophysiological investigations in the hippocampus. By contrast, little is known as to the way in which Nogo-A blockade promotes functional synapses in the adult damaged CNS. Oligodendrocyteexpressed Nogo-A also acts as a growth-restricting factor in the developing brain; in the visual cortex, the end of the activity-driven plastic phase of synapse sprouting, pruning and stabilization ("critical period") coincides with the myelination of layers IV-VI and the expression of Nogo-A. Nogo restricts the plasticity of the ocular dominance columns in the adult visual cortex in an NgR1-dependent manner, as shown by Nogo-KO and NgR1-KO mice analyses. Nogo/NgR1 signaling might therefore be a contributor to the end of the plastic so-called "critical period" (McGee et al. 2005).

In the adult hippocampus in which synaptic plasticity remains elevated throughout life, Nogo-A is highly expressed in pre- and postsynaptic neurons including CA3 and CA1 pyramidal cells (Lee et al. 2008). The addition of functionblocking anti-Nogo-A antibodies or Nogo-A KO induces marked changes in the complexity of the basal and apical dendritic arbors of CA1 and CA3 neurons and leads to massive sprouting of the CA3 axons (Zagrebelsky et al. 2010). The proportion of immature spines is also higher in the CA3 neurons. The dendritic and spine phenotypes can be reproduced by silencing NgR1 expression. Nogo-A thus appears here again as a stabilizer of synapses, the suppression of which leads to growth and higher plasticity in axons and dendrites. Electrophysiological recordings in acute hippocampal slices have revealed that the inactivation of Nogo-A or NgR1 with function-blocking antibodies or KOs increases LTP (Raiker et al. 2010; Delekate et al. 2011). Whether both neuronal and 
glial Nogo-A influence synapse remodeling and LTP is not known.

\section{Concluding remarks}

Nogo-A appears to be a major inhibitor of axonal regeneration; it induces the quick destabilization of the actin cytoskeleton and, on a longer time scale, represses growth gene expression. Many studies have reported that the neutralization of Nogo-A or Nogo-A receptor elements restores plasticity, improves axonal growth and enhances behavioral recovery after injury with no obvious side-effects. The high significance of these results has prompted to test the effects of function-blocking Nogo-A antibodies in patients with spinal cord injuries. Clinical trials are currently ongoing. In contrast, the physiological role of Nogo-A has been less-well studied. In the intact CNS, Nogo-A might contribute to stabilizing axonal connectivity (Park et al. 2010; Schwab 2010). Compelling evidence indicates that Nogo-A also modulates synaptic contacts and negatively influences LTP in the hippocampus. Thus, the physiological function of Nogo-A in the healthy brain might be to prevent abnormal sprouting and to regulate the dynamics of the synaptic cytoskeleton during learning processes. Future research will help us to understand the way that neuronal and glial Nogo-A regulates nerve fiber growth and connectivity and the fine tuning of synaptic plasticity in the developing and adult CNS.

\section{References}

Abel R, Baron H-C, Casha S, Harms J, Hurlbert J, Kucher K, Maier D, Thietje R, Weidner N, Curt A (2011) Therapeutic anti-Nogo-A antibodies in acute spinal cord injury: safety and pharmacokinetic data from an ongoing first-in-human trial. In: The International Spinal Cord Society (ISCoS) (eds) International Conference on Spinal Cord Medicine and Rehabilitation. Washington, D.C., USA, $\mathrm{p} 16$

Alabed YZ, Pool M, Ong Tone S, Sutherland C, Fournier AE (2010) GSK3 beta regulates myelin-dependent axon outgrowth inhibition through CRMP4. J Neurosci 30:5635-5643

Atkin JD, Farg MA, Turner BJ, Tomas D, Lysaght JA, Nunan J, Rembach A, Nagley P, Beart PM, Cheema SS, Horne MK (2006) Induction of the unfolded protein response in familial amyotrophic lateral sclerosis and association of protein-disulfide isomerase with superoxide dismutase 1. J Biol Chem 281:30152-30165

Atwal JK, Pinkston-Gosse J, Syken J, Stawicki S, Wu Y, Shatz C, Tessier-Lavigne M (2008) PirB is a functional receptor for myelin inhibitors of axonal regeneration. Science 322:967-970

Baldwin KT, Raiker S, Giger RJ (2011) Nogo-A negatively regulates mTor signaling to inhibit synaptic function. In: Society For Neuroscience (eds) Neuroscience 2011. Society For Neuroscience, Washington, p 216.04

Bareyre FM, Haudenschild B, Schwab ME (2002) Long-lasting sprouting and gene expression changes induced by the monoclonal antibody IN-1 in the adult spinal cord. J Neurosci 22:70977110
Bareyre FM, Kerschensteiner M, Raineteau O, Mettenleiter TC, Weinmann O, Schwab ME (2004) The injured spinal cord spontaneously forms a new intraspinal circuit in adult rats. Nat Neurosci 7:269-277

Bareyre FM, Garzorz N, Lang C, Misgeld T, Buning H, Kerschensteiner M (2011) In vivo imaging reveals a phase-specific role of STAT3 during central and peripheral nervous system axon regeneration. Proc Natl Acad Sci USA 108:6282-6287

Cafferty WB, Strittmatter SM (2006) The Nogo-Nogo receptor pathway limits a spectrum of adult CNS axonal growth. J Neurosci 26:1224212250

Cafferty WB, Duffy P, Huebner E, Strittmatter SM (2010) MAG and OMgp synergize with Nogo-A to restrict axonal growth and neurological recovery after spinal cord trauma. J Neurosci 30:68256837

Cai D, Deng K, Mellado W, Lee J, Ratan RR, Filbin MT (2002) Arginase I and polyamines act downstream from cyclic AMP in overcoming inhibition of axonal growth MAG and myelin in vitro. Neuron 35:711-719

Cheatwood JL, Emerick AJ, Schwab ME, Kartje GL (2008) Nogo-A expression after focal ischemic stroke in the adult rat. Stroke 39:2091-2098

Chen MS, Huber AB, Haar ME van der, Frank M, Schnell L, Spillmann AA, Christ F, Schwab ME (2000) Nogo-A is a myelin-associated neurite outgrowth inhibitor and an antigen for monoclonal antibody IN-1. Nature 403:434-439

Chivatakarn O, Kaneko S, He Z, Tessier-Lavigne M, Giger RJ (2007) The Nogo-66 receptor NgR1 is required only for the acute growth cone-collapsing but not the chronic growth-inhibitory actions of myelin inhibitors. J Neurosci 27:7117-7124

Delekate A, Zagrebelsky M, Kramer S, Schwab ME, Korte M (2011) NogoA restricts synaptic plasticity in the adult hippocampus on a fast time scale. Proc Natl Acad Sci USA 108:2569-2574

Dergham P, Ellezam B, Essagian C, Avedissian H, Lubell WD, McKerracher L (2002) Rho signaling pathway targeted to promote spinal cord repair. J Neurosci 22:6570-6577

Dimou L, Schnell L, Montani L, Duncan C, Simonen M, Schneider R, Liebscher T, Gullo M, Schwab ME (2006) Nogo-A-deficient mice reveal strain-dependent differences in axonal regeneration. J Neurosci 26:5591-5603

Doyle KM, Kennedy D, Gorman AM, Gupta S, Healy SJ, Samali A (2011) Unfolded proteins and endoplasmic reticulum stress in neurodegenerative disorders. J Cell Mol Med 15:2025-2039

Duffy P, Schmandke A, Sigworth J, Narumiya S, Cafferty WB, Strittmatter SM (2009) Rho-associated kinase II (ROCKII) limits axonal growth after trauma within the adult mouse spinal cord. J Neurosci 29:15266-15276

Dupuis L, Gonzalez de Aguilar JL, Scala F di, Rene F, Tapia M de, Pradat PF, Lacomblez L, Seihlan D, Prinjha R, Walsh FS, Meininger V, Loeffler JP (2002) Nogo provides a molecular marker for diagnosis of amyotrophic lateral sclerosis. Neurobiol Dis 10:358-365

Fournier AE, GrandPre T, Strittmatter SM (2001) Identification of a receptor mediating Nogo-66 inhibition of axonal regeneration. Nature 409:341-346

Fournier AE, Takizawa BT, Strittmatter SM (2003) Rho kinase inhibition enhances axonal regeneration in the injured CNS. J Neurosci 23:1416-1423

Freund P, Schmidlin E, Wannier T, Bloch J, Mir A, Schwab ME, Rouiller EM (2006) Nogo-A-specific antibody treatment enhances sprouting and functional recovery after cervical lesion in adult primates. Nat Med 12:790-792

Freund P, Schmidlin E, Wannier T, Bloch J, Mir A, Schwab ME, Rouiller EM (2009a) Anti-Nogo-A antibody treatment promotes recovery of manual dexterity after unilateral cervical lesion in adult primates - re-examination and extension of behavioral data. Eur J Neurosci 29:983-996 
Fujita Y, Endo S, Takai T, Yamashita T (2011) Myelin suppresses axon regeneration by PIR-B/SHP-mediated inhibition of Trk activity. EMBO J 30:1389-1401

Gao Y, Deng K, Hou J, Bryson JB, Barco A, Nikulina E, Spencer T, Mellado W, Kandel ER, Filbin MT (2004) Activated CREB is sufficient to overcome inhibitors in myelin and promote spinal axon regeneration in vivo. Neuron 44:609-621

Gonzenbach RR, Schwab ME (2008) Disinhibition of neurite growth to repair the injured adult CNS: focusing on Nogo. Cell Mol Life Sci 65:161-176

Gonzenbach RR, Zoerner B, Schnell L, Weinmann O, Mir AK, Schwab ME (2012) Delayed anti-Nogo-A antibody application after spinal cord injury shows progressive loss of responsiveness. J Neurotrauma 29:567-578

GrandPre T, Nakamura F, Vartanian T, Strittmatter SM (2000) Identification of the Nogo inhibitor of axon regeneration as a Reticulon protein. Nature 403:439-444

He W, Lu Y, Qahwash I, Hu XY, Chang A, Yan R (2004) Reticulon family members modulate BACE1 activity and amyloid-beta peptide generation. Nat Med 10:959-965

Huber AB, Weinmann O, Brosamle C, Oertle T, Schwab ME (2002) Patterns of Nogo mRNA and protein expression in the developing and adult rat and after CNS lesions. J Neurosci 22:3553-3567

Ji B, Li M, Wu WT, Yick LW, Lee X, Shao Z, Wang J, So KF, McCoy JM, Pepinsky RB, Mi S, Relton JK (2006) LINGO-1 antagonist promotes functional recovery and axonal sprouting after spinal cord injury. Mol Cell Neurosci 33:311-320

Jokic N, Gonzalez de Aguilar JL, Pradat PF, Dupuis L, Echaniz-Laguna A, Muller A, Dubourg O, Seilhean D, Hauw JJ, Loeffler JP, Meininger V (2005) Nogo expression in muscle correlates with amyotrophic lateral sclerosis severity. Ann Neurol 57:553-556

Jokic N, Gonzalez de Aguilar JL, Dimou L, Lin S, Fergani A, Ruegg MA, Schwab ME, Dupuis L, Loeffler JP (2006) The neurite outgrowth inhibitor Nogo-A promotes denervation in an amyotrophic lateral sclerosis model. EMBO Rep 7:1162-1167

Joset A, Dodd DA, Halegoua S, Schwab ME (2010) Pincher-generated Nogo-A endosomes mediate growth cone collapse and retrograde signaling. J Cell Biol 188:271-285

Kilic E, ElAli A, Kilic U, Guo Z, Ugur M, Uslu U, Bassetti CL, Schwab ME, Hermann DM (2010) Role of Nogo-A in neuronal survival in the reperfused ischemic brain. J Cereb Blood Flow Metab 30:969-984

Kim JE, Li S, GrandPre T, Qiu D, Strittmatter SM (2003) Axon regeneration in young adult mice lacking Nogo-A/B. Neuron 38:187-199

Lee JK, Kim JE, Sivula M, Strittmatter SM (2004) Nogo receptor antagonism promotes stroke recovery by enhancing axonal plasticity. J Neurosci 24:6209-6217

Lee H, Raiker SJ, Venkatesh K, Geary R, Robak LA, Zhang Y, Yeh HH, Shrager P, Giger RJ (2008) Synaptic function for the Nogo-66 receptor NgR1: regulation of dendritic spine morphology and activity-dependent synaptic strength. J Neurosci 28:2753-2765

Lee JK, Geoffroy CG, Chan AF, Tolentino KE, Crawford MJ, Leal MA, Kang B, Zheng B (2010) Assessing spinal axon regeneration and sprouting in Nogo-, MAG-, and OMgp-deficient mice. Neuron 66:663-670

Li S, Strittmatter SM (2003) Delayed systemic Nogo-66 receptor antagonist promotes recovery from spinal cord injury. J Neurosci 23:4219-4227

Liebscher T, Schnell L, Schnell D, Scholl J, Schneider R, Gullo M, Fouad K, Mir A, Rausch M, Kindler D, Hamers FP, Schwab ME (2005) Nogo-A antibody improves regeneration and locomotion of spinal cord-injured rats. Ann Neurol 58:706-719

Lord-Fontaine S, Yang F, Diep Q, Dergham P, Munzer S, Tremblay P, McKerracher L (2008) Local inhibition of Rho signaling by cellpermeable recombinant protein BA-210 prevents secondary damage and promotes functional recovery following acute spinal cord injury. J Neurotrauma 25:1309-1322

McGee AW, Yang Y, Fischer QS, Daw NW, Strittmatter SM (2005) Experience-driven plasticity of visual cortex limited by myelin and Nogo receptor. Science 309:2222-2226

Mi S, Lee X, Shao Z, Thill G, Ji B, Relton J, Levesque M, Allaire N, Perrin S, Sands B, Crowell T, Cate RL, McCoy JM, Pepinsky RB (2004) LINGO-1 is a component of the Nogo-66 receptor/p75 signaling complex. Nat Neurosci 7:221-228

Mi YJ, Hou B, Liao QM, Ma Y, Luo Q, Dai YK, Ju G, Jin WL (2012) Amino-Nogo-A antagonizes reactive oxygen species generation and protects immature primary cortical neurons from oxidative toxicity. Cell Death Differ (in press)

Montani L, Gerrits B, Gehrig P, Kempf A, Dimou L, Wollscheid B, Schwab ME (2009) Neuronal Nogo-A modulates growth cone motility via Rho-GTP/LIMK1/cofilin in the unlesioned adult nervous system. J Biol Chem 284:10793-10807

Nakamura Y, Fujita Y, Ueno M, Takai T, Yamashita T (2011) Paired immunoglobulin-like receptor B knockout does not enhance axonal regeneration or locomotor recovery after spinal cord injury. J Biol Chem 286:1876-1883

Nash M, Pribiag H, Fournier AE, Jacobson C (2009) Central nervous system regeneration inhibitors and their intracellular substrates. Mol Neurobiol 40:224-235

Niederost B, Oertle T, Fritsche J, McKinney RA, Bandtlow CE (2002) Nogo-A and myelin-associated glycoprotein mediate neurite growth inhibition by antagonistic regulation of RhoA and Rac1. J Neurosci 22:10368-10376

Oertle T, Klinger M, Stuermer CA, Schwab ME (2003a) A reticular rhapsody: phylogenic evolution and nomenclature of the RTN/Nogo gene family. FASEB J 17:1238-1247

Oertle T, Haar ME van der, Bandtlow CE, Robeva A, Burfeind P, Buss A, Huber AB, Simonen M, Schnell L, Brosamle C, Kaupmann K, Vallon R, Schwab ME (2003b) Nogo-A inhibits neurite outgrowth and cell spreading with three discrete regions. J Neurosci 23:5393-5406

Omoto S, Ueno M, Mochio S, Takai T, Yamashita T (2010) Genetic deletion of paired immunoglobulin-like receptor B does not promote axonal plasticity or functional recovery after traumatic brain injury. J Neurosci 30:13045-13052

Park KJ, Grosso CA, Aubert I, Kaplan DR, Miller FD (2010) p75NTRdependent, myelin-mediated axonal degeneration regulates neural connectivity in the adult brain. Nat Neurosci 13:559-566

Peng X, Kim J, Zhou Z, Fink DJ, Mata M (2011) Neuronal Nogo-A regulates glutamate receptor subunit expression in hippocampal neurons. J Neurochem 119:1183-1193

Pernet V, Joly S, Dalkara D, Schwarz O, Christ F, Schaffer D, Flannery JG, Schwab ME (2011) Neuronal Nogo-A upregulation does not contribute to ER stress-associated apoptosis but participates in the regenerative response in the axotomized adult retina. Cell Death Differ (in press)

Pradat PF, Corse A, Shefner J, Rothstein JD, Leigh PN, Morrison KE, et al (2011) A first-time-in-human study in ALS patients with the anti-Nogo-A monoclonal antibody GSK1223249. Preliminary results. In: 22nd international symposium on ALS/MND. Sydney, Australia

Raiker SJ, Lee H, Baldwin KT, Duan Y, Shrager P, Giger RJ (2010) Oligodendrocyte-myelin glycoprotein and Nogo negatively regulate activity-dependent synaptic plasticity. J Neurosci 30:12432-12445

Raineteau O, Fouad K, Noth P, Thallmair M, Schwab ME (2001) Functional switch between motor tracts in the presence of the mAb IN-1 in the adult rat. Proc Natl Acad Sci USA 98:6929-6934

Saxena S, Cabuy E, Caroni P (2009) A role for motoneuron subtypeselective ER stress in disease manifestations of FALS mice. Nat Neurosci 12:627-636

Schwab ME (2010) Functions of Nogo proteins and their receptors in the nervous system. Nat Rev Neurosci 11:799-811 
Shao Y, Akmentin W, Toledo-Aral JJ, Rosenbaum J, Valdez G, Cabot JB, Hilbush BS, Halegoua S (2002) Pincher, a pinocytic chaperone for nerve growth factor/TrkA signaling endosomes. J Cell Biol 157:679-691

Shao Z, Browning JL, Lee X, Scott ML, Shulga-Morskaya S, Allaire N, Thill G, Levesque M, Sah D, McCoy JM, Murray B, Jung V, Pepinsky RB, Mi S (2005) TAJ/TROY, an orphan TNF receptor family member, binds Nogo-66 receptor 1 and regulates axonal regeneration. Neuron 45:353-359

Shi Q, Hu X, Prior M, Yan R (2009a) The occurrence of aging-dependent reticulon 3 immunoreactive dystrophic neurites decreases cognitive function. J Neurosci 29:5108-5115

Shi Q, Prior M, He W, Tang X, Hu X, Yan R (2009b) Reduced amyloid deposition in mice overexpressing RTN3 is adversely affected by preformed dystrophic neurites. J Neurosci 29:9163-9173

Simonen M, Pedersen V, Weinmann O, Schnell L, Buss A, Ledermann B, Christ F, Sansig G, Putten H van der, Schwab ME (2003) Systemic deletion of the myelin-associated outgrowth inhibitor Nogo-A improves regenerative and plastic responses after spinal cord injury. Neuron 38:201-211

Spillmann AA, Bandtlow CE, Lottspeich F, Keller F, Schwab ME (1998) Identification and characterization of a bovine neurite growth inhibitor (bNI-220). J Biol Chem 273:19283-19293

Tagami S, Eguchi Y, Kinoshita M, Takeda M, Tsujimoto Y (2000) A novel protein, RTN-XS, interacts with both Bcl-XL and Bcl-2 on endoplasmic reticulum and reduces their anti-apoptotic activity. Oncogene 19:5736-5746

Thallmair M, Metz GA, Z'Graggen WJ, Raineteau O, Kartje GL, Schwab ME (1998) Neurite growth inhibitors restrict plasticity and functional recovery following corticospinal tract lesions. Nat Neurosci 1:124-131

Tsai SY, Papadopoulos CM, Schwab ME, Kartje GL (2011) Delayed anti-Nogo-a therapy improves function after chronic stroke in adult rats. Stroke 42:186-190
Voeltz GK, Prinz WA, Shibata Y, Rist JM, Rapoport TA (2006) A class of membrane proteins shaping the tubular endoplasmic reticulum. Cell 124:573-586

Wan Q, Kuang E, Dong W, Zhou S, Xu H, Qi Y, Liu Y (2007) Reticulon 3 mediates Bcl-2 accumulation in mitochondria in response to endoplasmic reticulum stress. Apoptosis 12:319-328

Wang KC, Kim JA, Sivasankaran R, Segal R, He Z (2002a) P75 interacts with the Nogo receptor as a co-receptor for Nogo, MAG and OMgp. Nature 420:74-78

Wang X, Chun SJ, Treloar H, Vartanian T, Greer CA, Strittmatter SM (2002b) Localization of Nogo-A and Nogo-66 receptor proteins at sites of axon-myelin and synaptic contact. J Neurosci 22:5505-5515

Wang X, Baughman KW, Basso DM, Strittmatter SM (2006) Delayed Nogo receptor therapy improves recovery from spinal cord contusion. Ann Neurol 60:540-549

Wang X, Duffy P, McGee AW, Hasan O, Gould G, Tu N, Harel NY, Huang Y, Carson RE, Weinzimmer D, Ropchan J, Benowitz LI, Cafferty WB, Strittmatter SM (2011) Recovery from chronic spinal cord contusion after Nogo receptor intervention. Ann Neurol 70:805-821

Yang YS, Harel NY, Strittmatter SM (2009) Reticulon-4A (Nogo-A) redistributes protein disulfide isomerase to protect mice from SOD1-dependent amyotrophic lateral sclerosis. J Neurosci 29:1385013859

Yin Y, Cui Q, Li Y, Irwin N, Fischer D, Harvey AR, Benowitz LI (2003) Macrophage-derived factors stimulate optic nerve regeneration. J Neurosci 23:2284-2293

Zagrebelsky M, Schweigreiter R, Bandtlow CE, Schwab ME, Korte M (2010) Nogo-A stabilizes the architecture of hippocampal neurons. J Neurosci 30:13220-13234

Zheng B, Ho C, Li S, Keirstead H, Steward O, Tessier-Lavigne M (2003) Lack of enhanced spinal regeneration in Nogo-deficient mice. Neuron 38:213-224

Zorner B, Schwab ME (2010) Anti-Nogo on the go: from animal models to a clinical trial. Ann N Y Acad Sci 1198(Suppl 1):E22-E34 